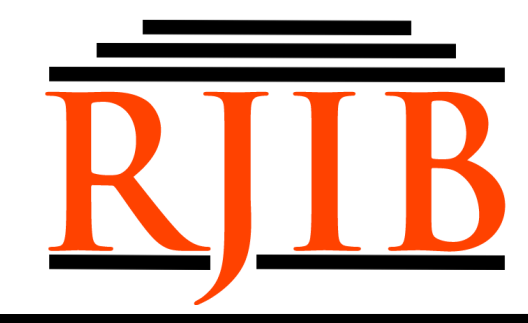

RETORIKA: Jurnal Ilmu Bahasa

Vol. 6, No. 1 April 2020, Page 26-32

\title{
Manipulation And Persuasion Through Language Features In Fake News
}

\begin{tabular}{l} 
Agus Ari Iswara* and Kadek Agus Bisena \\
STMIK STIKOM Indonesia \\
*ari.iswara@stiki.indonesia.ac.id \\
\begin{tabular}{|lc|}
\hline Received: $19 / 09 / 2019$ & Revised: $23 / 04 / 2020$ \\
\hline How to cite (in APA style): \\
Iswara, A, A., Bisena, K, A. (2020). Manipulation And Persuasion Through Language Features In Fake News. \\
RETORIKA: Jurnal Ilmu Bahasa, 6(1), 26-32. doi: https://doi.org/10.22225/jr.6.1.1338.26-32
\end{tabular} \\
\hline
\end{tabular}

\begin{abstract}
This study attempts to describe the use of language features in hoaxes to manipulate facts and describe their persuasive power in influencing readers. This research is a qualitative descriptive study. This research data is documented from turnbackhoax.id. This site was chosen because it is one of the most popular hoax repellent sites in Indonesia. Documentation was the method of data collection. Data were collected then classified, organized, and then analyzed using theoretical concepts. Theory used to analyze language manipulation in this research is Barton and Lee's theory of language features and Searle theory of speech acts. Data and analysis are presented in tables with brief descriptions. The results of this study indicates that hoax maker use language features in manipulating facts, those are (1) acronyms and initialisms, (2) word reduction, (3) letters or numbers, (4) stylized/unconventional spelling, (5) emoticons, (6) stylized/unconventional punctuation, and (7) images or photographs. Furthermore, it is found the use of assertive, expressive and directive speech acts to build persuasive power to influence the reader. The results of this study can be used as a reference in seeing the characteristics of language manipulation on hoaxes so that people can maximize the use of their logic and intellectual as a system of verifying information to determine the truth of information, knowing the information is fact or fake, distinguishing an information is a hoax or fact.
\end{abstract}

Keyword: hoax; hoax maker; language feature; manipulation; persuasion

\section{INTRODUCTION}

Browsing information on digital media has become one of the needs of the community that causes raise the number of new online news portals. Content of the online news portal can be easily shared on social media. In 2018 the Press Council stated that online or cyber media was estimated to reach 43.300 , but only 211 were recorded as professional media and qualified in 2014. The number was reduced to only 168 online media in 2015 (Nashrillah, 2018). Meanwhile, in January 2018 the Ministry of Communication and Information stated only 100 online news portals were verified (kominfo.go.id, 2018).

The ease way of browsing information on digital media through gadgets is also one of the triggers of hoax easily produced and disseminated, especially through website and social media. Hoax is information that is not true, but is made as if it were true (id.wikipedia.org). Data from the Ministry of Communication and Information states that there are around 800.000 websites in Indonesia that have been indicated as spreading fake news (Pratama, 2016). Then in 2018 the State Intelligence Agency stated 60 percent of social media content was hoax (Meiliana, 2018).

Fake news makers on digital media use language as the instrument to manipulate facts and produce lies. Mey stated that the manipulation instrument most often used was language (Mey, 1994, p. 296) As a 
communication device that functions to deliver information, language can influence the reader's ideas and can touch the emotions of the reader. Language has features and has a persuasive effect on its users. Barton and Lee state that youth languages in communication using digital technology are characterized by the following features, namely acronyms and initialisms, reduction words, letters or homophonic numbers, stylized spelling, emoticons, and stylized/unconventional punctuation (Barton \& Lee, 2013, p. 5). Look at one of the documented hoax from turnbackhoax.id below:

Table 1.

Documented hoax from turnbackhoax.id

"Lihat baik2..ini bukan gn.Fuji.di jepang...bukan juga pegunungan Alpen di eropa...tapi ini gn.Dieng Salatiga...Indonesia..suhu $-9^{\circ} \mathrm{C}$ "

[Look carefully.. this is not Mt.Fuji.in Japan ... nor the Alps in Europe ... but this is Mt.Dieng Salatiga...Indonesia..temperature $\left.-9^{\circ} \mathrm{C}\right]$

The hoax makers express the repetition of words using number "2" in the "baik2", punctuation in the form of the period "." in unconventional composition "..." and reduce the word "mountain" into "gn.". Hoaxes are produced and spread at aim of influencing the reader, certainly hoax has persuasive power.

A new language in communication in digital technology is characterized by the following features, namely (a) acronyms and initialisms, (b) word reduction, (c) letters or homophonic numbers, (d) stylized spelling, (e) emoticons, and (f) stylized/unconventional punctuation (Barton \& Lee, 2013, p. 5).

Besides that, speech acts are classified into five types, namely assertive or representative speech acts, commission speech acts, expressive speech acts, declarative speech acts and directive speech acts. According to (Darmayanti, Nurhadi, \& Yubiliana, 2014) characteristics of assertive are in the form of declarative sentences (delivery of information) which function is to inform about a fact, result, description, affirmation, and conclusion. The speaker uses his speech in accordance with reality. According to (Djatmika, 2016) assertiveness is all speech related to the speaker propositions, both true and false. Assertive is usually marked by verbs that imply "state", "say", "explain", "describe", "tell", "comment", "approve", and "provide information". According to (Yayuk, 2016) assertive speech acts relate to stating something, linking the speaker to the facts being told. In general, this speech act used to state something, express an opinion, claim, speculate, and report. Thus, assertive or representative speech acts linking the speaker to the truth of the proposition conveyed. This speech act is marked by the use or at least implies "say", "state", "explain", "suggest", "describe", "tell", "comment", "approve", "give information", "complaining", "claiming", "criticizing", "reporting", and "reminding".

Furthermore, the commission speech act according to (Partana, 2020) is a speech delivered by a speaker to the speech partner about his willingness to do something, such as giving a promise to be done in the future. Commission realization is usually in a critical condition so that the speech partner gives confidence to the speaker. According to (Wicaksono, 2015) commission speech acts are speech acts to express intention to do something for the speech partners. The intention is done by the speaker with sincerity. These actions have not been carried out and will be carried out in the future. Commission speech acts are carried out by the speaker by stating a promise to the speech partner to do something. According to (Djatmika, 2016) commission speech acts are speeches where the speaker makes a commitment to take action in the future for the speech partner. Commission speech acts are usually marked by the phrase "swear", "promise", "make a pledge", and others. Thus, commission speech acts are delivered using diction that implies or contains promises, vows, offers, and contracts.

Expressive speech acts refer to the emotional feelings of the speaker. According to (Djatmika, 2016) expressive speech acts are marked by expressions of condolence, thanking, praising, insulting, saying goodbye, apologizing, blaming, and so on. So, expressive speech acts are emotional expressions of the speaker, for example the speaker expresses his feelings to the speech partner, the speech used is expressive. This expression is used to express things related to the inner feelings that are felt.

Next, according to Searle, declarative speech acts refer to speakers who reconstruct or change the reality in the world. Declarative 
speech acts transform one condition into another condition. According to Searle, the declarative speech act category is a very specific illocutionary act. Declarative acts are carried out by someone who has a specific duty to do so in institutional work plans, for example judge who sentence defendants, officials or people who have positions inaugurating the event, priests who marry the bride.

The directive speech acts according to (Yule, 2006) are used to give orders to the speech partners. This speech act contains orders, requests, and provides advice. The form of speech can be in the form of positive and negative sentences. Verbs that are used imply instructions, such as ordering, instructing, asking, suggesting, prohibiting, inviting, confirming, and so on. According to (Thamrin, 2010) directive speech acts aim to produce an influence in the form of actions. (Darmayanti et al., 2014) added that directive speech acts are realized in the form of imperative sentences to give orders using performativity verbs. According to (Djatmika, 2016) to make speech partners take action or not take action, speakers will use directive speech.

Based on the description above, this study aims to describe the use of language features in hoaxes to manipulate facts and describe their persuasive power in influencing readers.

\section{METHODS}

This research is a qualitative descriptive study that describes manipulation and persuasion with language features in hoax. The object of the study is fake news that contains manipulative content. Data in this study were collected from turnbackhoax.id. Its source of content was from Forum Anti Fitnah Hasut dan Hoax (FAFHH). This site was chosen because it is one of the popular hoax repellent sites in Indonesia and it is managed by Masyarakat Anti Hoax Indonesia (MAFINDO). MAFINDO is an official organization that was established on 19 November 2016. The documentation technique is used to capture news that has been confirmed as a hoax on the site. Data that has been documented then processed by through verification and classification. Next, the data is presented on tables with an analysis in the form of descriptions, and the last, composing the conclusions.

Theory are applied to analyze language manipulation in this research is Barton and Lee's theory that are characterized language features into (a) acronyms and initialisms, (b) word reduction, (c) letters or homophonic numbers, (d) stylized spelling, (e) emoticons, and (f) stylized/unconventional punctuation (Barton \& Lee, 2013, p. 5). The second theory is the theory of speech acts from Searle which classifies speech acts into five types, namely assertive or representative speech acts, commission speech acts, expressive speech acts, declarative speech acts and directive speech acts. The theory is applied as a reference for analyzing the persuasive power of speech. Then, Suci and Indra Iswara added that the picture or photo was also used in hoax. Verifying photos can be done by using the search engine "Google Photo", using the Exif Viewers application from Jeffrey, or checking photos using the facilities from the site www.wolframalpha.com (Meinarni \& Iswara, 2018).

\section{RESULTS AND DISCUSSION}

Based on theoretical concept, it is found that hoax maker use language features as the instruments to manipulate facts. In data found the use of manipulative text and images that are different from the original content, composition of letters and numbers, unconventional punctuation, the use of foreign words. It is accordant as (Asya, 2013) state that the characteristic of manipulation are through a unit and category in the form of foreign words, euphemisms, figurative speech, inappropriate content with the original content, and different compositions. Data can be seen in table 2 .

Table 2.

Data

\begin{tabular}{ll}
\hline Nomor & Data \\
1. & "Tanggapi People Power, UYM: Jihad Bela Prabowo “Mati Syahid”, Namun Pasti Masuk Neraka!!”
\end{tabular}

[Respond to People Power, UYM: Jihad defense Prabowo "Dead Syahid", But Surely Go To Hell!!] 


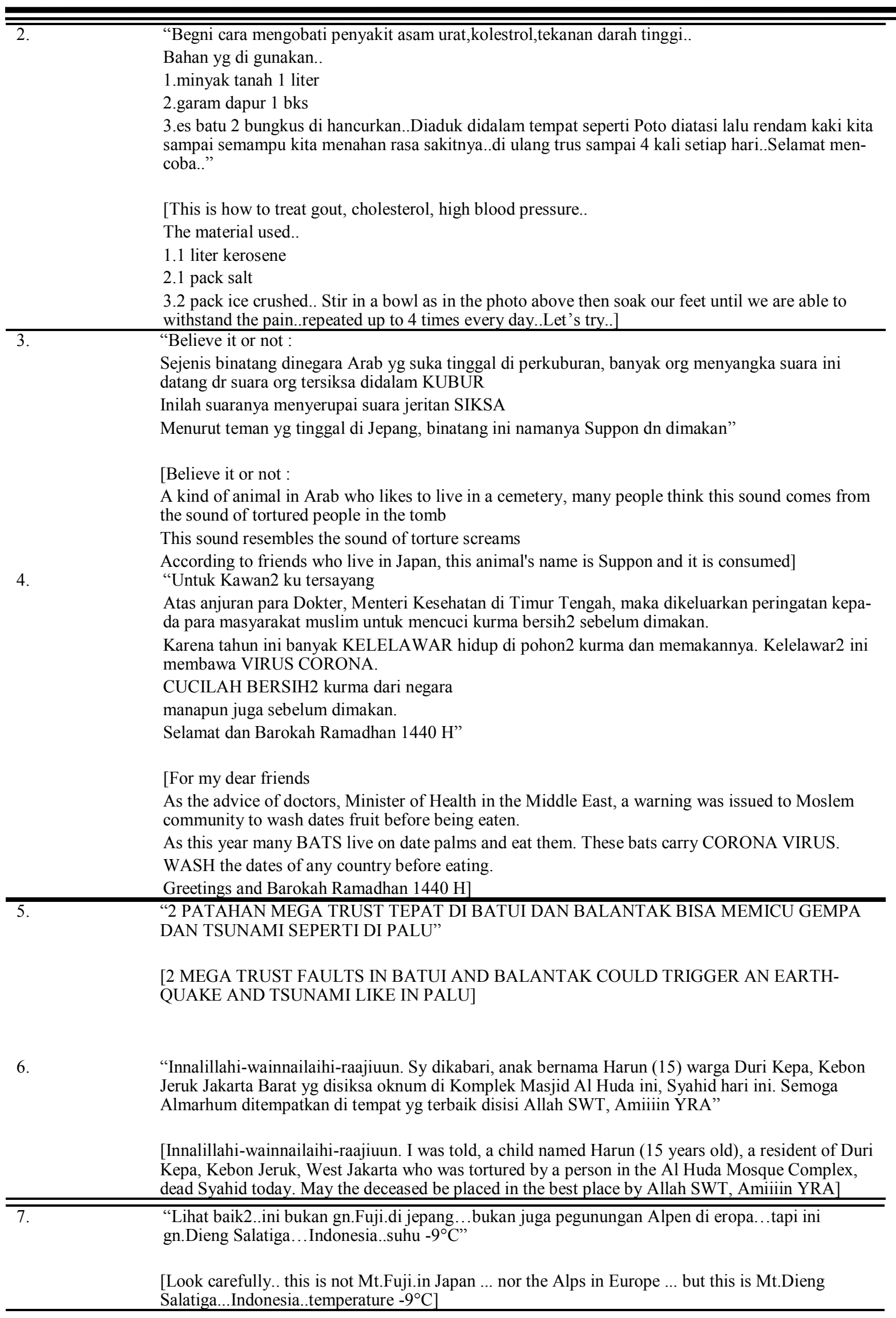




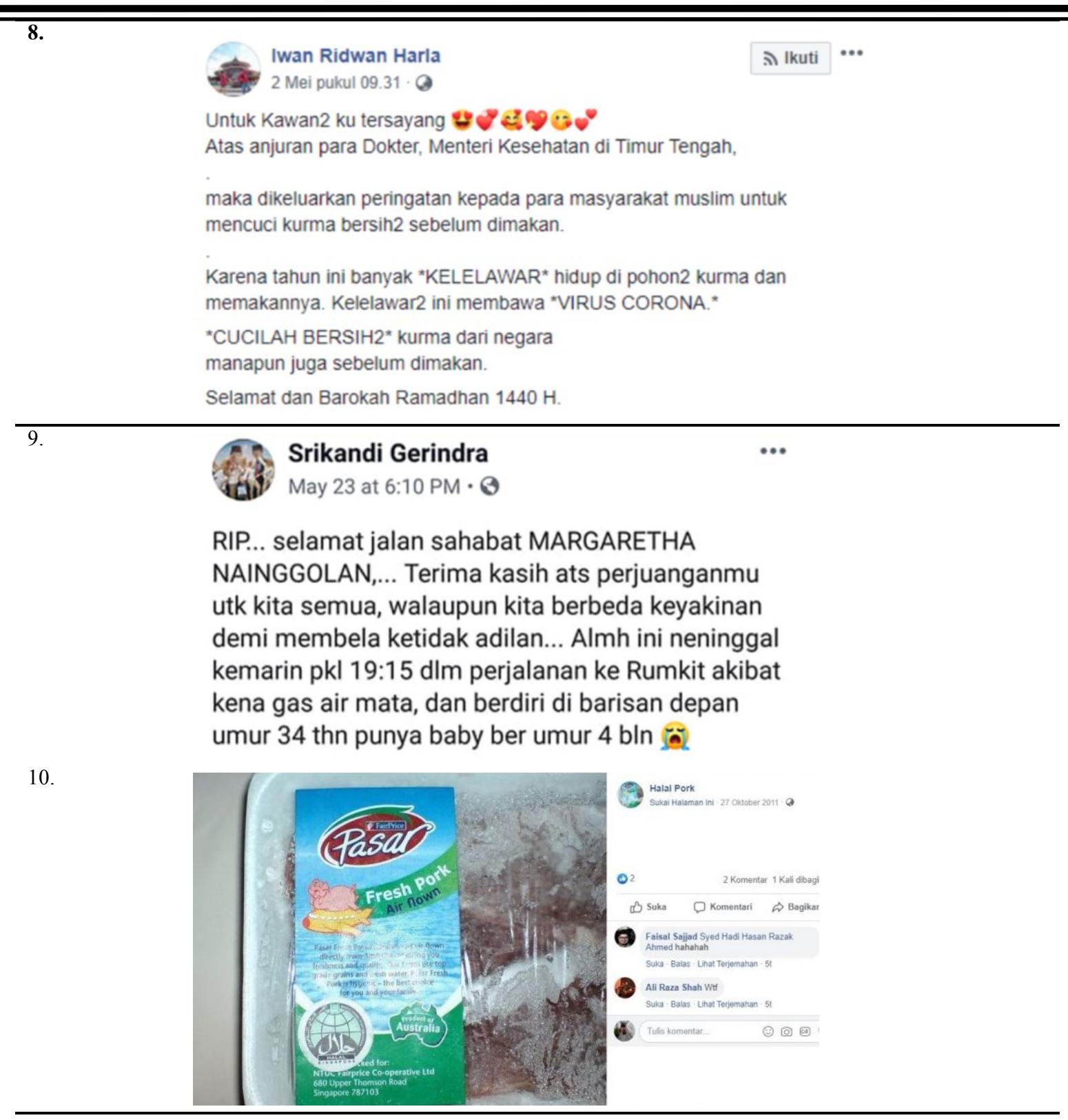

\section{Manipulation Using Language Features}

Barton and Lee stated that various new languages in communication using digital technology are characterized by the following features, namely (a) acronyms and initialisms, for example "GTG" for "got to go"; "LOL" for "laugh out loud", (b) word reductions, for example "gd" for "good"; "hv" for "have", (c) letters or numbers homophones, for example "U" for "you"; "2" for "to", (d) stylized spelling, for example "I'm soooooooooo happy!", (e) emoticons, such as :-) and :(), (f) unconventional/stylized punctuation, for example “!!!!!!!" or "..................." (Barton $\&$ Lee, 2013, p. 5). The use of letters and numbers can be unconventional writing styles such as using full capital letters and repetition of words using number "2". Furthermore, (Meinarni \& Iswara, 2018) stated that hoax also used (g) manipulated images or photos. The use of those language features in the data can be seen in table 3 . 
Table 3

The use of language features

\begin{tabular}{|c|c|c|}
\hline Language Features & Number of Data & Use of Language Features \\
\hline Acronyms and initialisms & 1,6 & $\begin{array}{l}\text { UYM (Ustad Yusuf Mansyur), SWT (Subhanahu Wa } \\
\text { Ta'ala) }\end{array}$ \\
\hline Word reductions & $3,6,7$ & Begni, bks, trus, yg, org, dr, dn, YRA, gn. \\
\hline Letters or numbers & $3,4,5,7$ & $\begin{array}{l}\text { KUBUR, SIKSA, Kawan2, bersih2, pohon2, Kele- } \\
\text { lawar2, VIRUS CORONA, CUCILAH BERSIH2, } \\
\text { PATAHAN...DI PALU }\end{array}$ \\
\hline Stylized spelling & 6 & Amiiiin \\
\hline Emoticon & 8,9 & 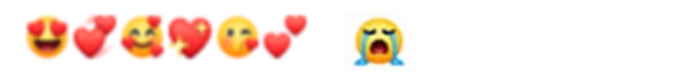 \\
\hline Stylized Punctuations & $1,2,7$ & $! !, . ., \ldots$ \\
\hline Images or photos & 10 & image "Halal Pork" \\
\hline
\end{tabular}

\section{Persuasive Function}

Based on the concept of Searle's speech act theory, it is found that hoax makers use language features in the form of assertive speech acts, expressive speech acts, and directive speech acts in conveying fake information that contains persuasive power to influence the readers. Hoax makers use language to facilitate the distortion of reality, creating inaccuracies and ambiguity. The persuasive function of language features can be seen in the following table.

Table 4.

Persuasive function of language features

\begin{tabular}{|c|c|c|}
\hline Speech acts & Language Feature & Persuasive Function \\
\hline \multirow{7}{*}{ Assertive } & UYM, SWT & convey fake information; \\
\hline & $\begin{array}{l}\text { Begni, bks, trus, yg, org, dr, dn, } \\
\text { YRA, gn. }\end{array}$ & convey fake information with efficient word forms \\
\hline & KUBUR, SIKSA, VIRUS CO- & convey fake information; \\
\hline & RONA & $\begin{array}{l}\text { showing emphasis; } \\
\text { attract reader's attention through the urgency and ex- } \\
\text { citement }\end{array}$ \\
\hline & PATAHAN...DI PALU & convey fake information; \\
\hline & $\begin{array}{l}\text { Kawan2, bersih2, pohon2, Kele- } \\
\text { lawar2 }\end{array}$ & convey fake information; \\
\hline & Image "Halal Pork" & convey fake information with manipulated image \\
\hline \multirow{2}{*}{ Expressive } & $20 c^{2} 69.0$ & $\begin{array}{l}\text { express sympathy; } \\
\text { attract the reader's attention }\end{array}$ \\
\hline & (ด) & express empathy and sadness \\
\hline Directive & CUCILAH BERSIH2 & stating command or order \\
\hline
\end{tabular}

\section{IV.CONCLUSION}

The results of this study indicate that the hoax makers use language features to build manipulated content for creating distortions of reality, creating inaccuracies and ambiguity. The language features used consist of acronyms and initialisms, 
reduction of words, letters or numbers, stylized/unconventional spelling, emoticons, stylized/unconventional punctuation, and manipulated images or photos. Furthermore, it is found the use of assertive, expressive, and directive speech acts to build persuasive power for leading the reader's ideas, influence the reader to share the hoax, or take action as the order of content of the information.

\section{REFERENCES}

Asya, A. (2013). Linguistic Manipulation: Definition and Types. International Journal of Cognitive Research in Science, 1(2).

Barton, D., \& Lee, C. (2013). Language Online: Investigating Digital Texts and Practices. Oxon: Routledge.

Darmayanti, N., Nurhadi, J., \& Yubiliana, G. (2014). Tipe Tindak Tutur Dalam Komunikasi Dental Hipnosis : Suatu Kajian Pragmatik. Ranah, 3(1), 135-142.

Djatmika. (2016). Mengenal Pragmatik Yuk!? Yogyakarta: Pustaka Pelajar.

kominfo.go.id. (2018). Menkominfo: Baru 100 Portal Berita Online Terverifikasi. Retrieved from https://kominfo.go.id/content/ detail/12345/menkominfo-baru-100-portalberita-online-terverifikasi/0/berita_satker

Meiliana, N. A. (2018). BIN: 60 Persen Konten Media Sosial adalah Informasi Hoaks. Retrieved from https://nasional.kompas.com/ $\mathrm{read} / 2018 / 03 / 15 / 06475551 / \mathrm{bin}-60$-persenkonten-media-sosial-adalah-informasi-hoaks

Meinarni, N. P. S., \& Iswara, I. B. A. I. (2018). Hoax and its Mechanism in Indonesia (Vol. 165, pp. 183-186).

Mey, J. L. (1994). Pragmatics: An Introduction. USA: Blackwell.

Nashrillah, F. (2018). Dewan Pers: Ada 43 Ribu Media Online, Hanya 168 Yang Profesional. Retrieved from https://www.idntimes.com/ news/indonesia/faiz-nashrillah/dewan-persada-43-ribu-media-online-hanya-168-yangprofesional-1

Partana, P. (2020). Pola Tindak Tutur Komisif Beranji Bahasa Jawa. WidyaparWa, 38(1), 15-22.

Pratama, A. B. (2016). Ada 800 Ribu Situs Penyebar Hoax di Indonesia. Retrieved from https://www.cnnindonesia.com/ teknologi/20161229170130-185-182956/ada800-ribu-situs-penyebar-hoax-di-indonesia dalam Interaksi Kelas Bengkel Jurusan Teknik Mesin Politeknik Negeri Malang. LITERA, 9(1), 91-101.

Wicaksono, A. (2015). Tindak Tutur Komisif Pementasan Drama " Mangir Wanabaya " ( Suatu Tinjauan Sosiopragmatik). Ranah, $4(1)$.

Yayuk, R. (2016). Wujud Kesantunan Asertif dan Imperatif dalam Bahasa Banjar. Ranah, 5(2), $115-124$

Yule, G. (2006). Pragmatik. Yogyakarta: Pustaka Pelajar.

Thamrin, M. (2010). Ekspresi Tindak Direktif 